http://dx.doi.org/10.18778/0208-6050.95.07

JOANNA JASITCZAK

(UNIWERSYTET ŁÓDZKI) ${ }^{*}$

\title{
Muzyczny Wiedeń Wolfganga Amadeusza Mozarta (1781-1791)
}

Wiedeń, od XIII w. siedziba Habsburgów i stolica wielonarodowej monarchii obejmującej: Niemcy, Austrię, Czechy, Morawy i Węgry, Górną Italię oraz część Śląska i Łużyc, w okresie klasycyzmu muzycznego był widownią przemian właściwych całej Europie. Światła polityka cesarzowej Marii Teresy (1740-1780) oraz jej syna Józefa II (1765-1790), a przede wszystkim złagodzenie cenzury sprawiły, że Wiedeń stał się miastem atrakcyjnym dla artystów. Dla Habsburgów muzyka, literatura i teatr były dopełnieniem władzy, dodawały jej majestatu i polotu. Ceremoniał dworski pozostawiał wiele miejsca dla wszelkiego rodzaju imprez kulturalnych z okazji np. narodzin, chrzcin, imienin, urodzin, zaślubin, świąt religijnych, ważnych wizyt dyplomatycznych czy zawieranych umów międzynarodowych. Wydarzenia te zawsze stanowiły doskonały pretekst do urządzania balów, spektakli teatralnych, koncertów lub innych form rozrywki. Od wczesnych lat panowania Habsburgowie mieli własne „państwo teatralne”. Podlegało ono ochmistrzowi dworu, a składało się z nadwornej kapeli, nadwornego kapelmistrza, muzyków, śpiewaków, tancerzy i baletmistrzów oraz architektów teatralnych. Członkowie rodziny cesarskiej, w tym wspomniana Maria Teresa oraz jej dzieci: Józef II i Maria Antonina, reprezentowali dość wysoki stopień umuzykalnienia.

Lata panowania Marii Teresy i Józefa II pokrywają się z latami życia trzech znaczących kompozytorów: Josepha Haydna (1732-1809), Wolfganga Amadeusza Mozarta (1756-1791) oraz Ludwiga van Beethovena (1770-1827). Ich twórczość wniosła tak wiele, że w dziejach muzyki okres ich działań uznaje się za oddzielną epokę, zwaną klasycyzmem wiedeńskim. Za jego początek uznaje się rok 1750, czyli rok śmierci Jana Sebastiana Bacha. Koniec zaś przypada na okolice roku 1820 , kiedy zaczęly się szerzyć prądy romantyczne.

Jeśli zliczymy śpiewaków, kościelnych i wojskowych muzyków, członków kameralnych i prywatnych orkiestr, nauczycieli gry na fortepianie i instrumentalistów, możemy przyjąć, że w liczącym wówczas 250 tys. mieszkańców Wiedniu

\footnotetext{
* Wydział Filozoficzno-Historyczny, Instytut Historii, Katedra Historii Nowożytnej.
} 
ponad 1000 to muzycy ${ }^{1}$. Ponadto $\mathrm{w}$ mieście powstały liczne warsztaty produkujące instrumenty oraz wydawnictwa muzyczne, a obecność wielu szlachetnie urodzonych mecenatów zapewniała muzykom protekcję i zamówienia. Wiedeń stanowił więc w owym czasie, w znacznie większym stopniu niż Monachium czy Drezno, kulturalne centrum całego obszaru niemieckojęzycznego. Stworzono wówczas podwaliny życia muzycznego, które w tym kształcie trwa do dziś. Nic więc dziwnego, że miasto to zostało określone mianem stolicy muzyki klasycznej ${ }^{2}$.

$\mathrm{W}$ artykule chciałabym przybliżyć, jak w tym muzycznym Wiedniu odnajdował się jeden ze wspomnianych klasyków - Wolfgang Amadeusz Mozart, przez wielu uznawany za największego kompozytora w dziejach muzyki.

Ostatnie dziesięć lat swojego życia, które Mozart spędził w Wiedniu, więc lata 1781-1791, niemalże zbiegły się z rządami Józefa II, który objął władzę nad Cesarstwem po śmierci swej matki - cesarzowej Marii Teresy (29 listopada 1780 r.). Osobowość i program nowego władcy odcisnęły silne piętno na monarchii habsburskiej. Okres jego rządów, czyli lata 1780-1790, nazywany jest „epoką józefińską” bądź też „dziesięcioleciem odwilży”.

Nowego władcę wyróżniało przede wszystkim podejście do sprawowanego urzędu, traktując go jako misję w służbie poddanych. Zasada równości wszystkich ludzi - przede wszystkim wobec Boga, w konsekwencji również wobec prawa, była silnie podkreślana w różnych dekretach wydawanych przez cesarza ${ }^{3}$. Stanowiła wybitnie oświeceniowy rys w polityce państwowej Józefa II, który w przeciwieństwie do swej matki był otwarty na nowatorskie prądy swojej epoki.

Dziesięcioletnie rządy władcy charakteryzowały się przede wszystkim dążeniem do centralizacji państwa, czyli zjednania narodów znajdujących się pod berłem habsburskim. Jednym z narzędzi do zrealizowania tego celu miała być kultura. Józef II poczynił więc kroki zmierzające do utworzenia niemieckiego Teatru Narodowego oraz udoskonalenia gatunku, jakim była niemiecka śpiewogra. W tym celu postanowił usunąć włoską trupę, a w jej miejsce zaangażować nowy zespół niemiecki. Traktował to zadanie na tyle poważnie, że osobiście pojawiał się na próbach, nakazał informować o decyzjach repertuarowych i obsadowych. Muzyka operowa rozwijała się tu znakomicie, mając zapewnioną baze w czterech oficjalnych teatrach: dwóch przy dworze cesarskim, w Burgtheater i Karntnertortheater, a także w wiejskich posiadłościach austrowęgierskiej arystokracji, utrzymującej orkiestry i nadwornych kompozytorów ${ }^{4}$.

\footnotetext{
${ }^{1}$ M. B e c k e r, Wolfgang Amadeusz Mozart. Biografia ilustrowana, Warszawa 2006, s. 94.

${ }^{2}$ D. B o e t t g e r, Mozart, Warszawa 2006, s. 23.

${ }^{3} \mathrm{~W}$ ciągu 10 lat panowania Józef II wydał ich ponad 6000; J. F e i t o, Józef II, Habsburg rewolucjonista, Warszawa 1990, s. 120.

${ }^{4}$ W. D u 1 ę b a, Mozart, Kraków 1977, s. 142.
} 
Można więc powiedzieć, że Mozart, przybywając 16 marca 1781 r. do stolicy, znalazł się we właściwym miejscu i we właściwym czasie. Jako rodowity Niemiec teoretycznie mógł liczyć na posadę w jednej z oper. Nadrzędnym celem 25-letniego wówczas kompozytora było zatem „wmieszanie się” w wiedeńskie środowisko muzyczne i uzyskanie dostępu do scen. Nieustannie dążył też do zdobycia stałej posady u boku cesarza. Tym bardziej że do Salzburga i tak nie miał po co wracać po słynnej awanturze z salzburskim pracodawcą - arcybiskupem Hieronimem Colloredo, do jakiej doszło podczas wizyty Mozarta w jego rodzinnym mieście 9 maja $1781 \mathrm{r}$. Kompozytor stawił wówczas czoła despotycznemu duchownemu, który zabronił muzykowi dawania koncertów na własny rachunek i nakazał powrót do Salzburga. Młody człowiek nie zastosował się do tych zaleceń, w wyniku czego arcybiskup wyzwał go od „wszarza, kretyna, rozpustnika i łajdaka", po czym wyrzucił za drzwi. Na drogę Mozart dostał jeszcze solidnego kopniaka od hrabiego d'Arco, przełożonego książęcej kuchni ${ }^{5}$.

Kiedy o zdarzeniu tym dowiedział się ojciec kompozytora - Leopold, nakazał synowi okazanie skruchy i jak najszybsze przeproszenie Colloreda. Mozart jednak ani myślał o przyznaniu się do winy, gdyż jak pisał do ojca: „cały Wiedeń wie, że odszedłem od arcybiskupa i wie również dlaczego [...], ponieważ został znieważony mój honor [...]"6. To ten dzień - 9 maja 1781 r. - można uznać za początek „wiedeńskiej dekady” w życiu artysty. Cała sytuacja wpłynęła jednak na oziębienie stosunków między ojcem i synem. Możemy się o tym przekonać chociażby z korespondencji, gdyż odtąd listy Wolfganga do ojca kończyły się suchymi formułkami w stylu: „posłuszny syn W.A. Mozart”, a nie ciepłymi pozdrowieniami, do jakich miał skłonność wcześniej.

W wielkiej stolicy został więc Wolfgang sam: bez posady, bez wstawiennictwa ojca, bez bliskiej mu osoby. Aby zarobić na utrzymanie, imał się przeróżnych zajęć, m.in. sprzedawał swoje utwory, udzielał lekcji gry na fortepianie. Pierwszą wiedeńską uczennicą była kuzynka wicekanclerza austriackiego Johanna Philipa von Cobenzla - Maria Karolina Thiennes de Rumbeke. Niestety nie udało mu się zostać nauczycielem księżniczki Elżbiety Wirtemberskiej ${ }^{7}$, o co długo zabiegał.

Nie dostał także posady u boku cesarza. Józef II miał bowiem inne plany wobec młodego kompozytora. Darzył go co prawda szacunkiem i podziwem, lecz nie zamierzał wiązać go stałą posadą. „Najwyższy mocodawca” postanowił dać szansę Mozartowi w inny sposób, mianowicie zamawiając u niego skompo-

${ }^{5}$ Ibidem.

${ }^{6}$ Ibidem.

${ }^{7}$ Elżbieta Wirtemberska (1767-1790) - księżniczka wirtemberska, arcyksiężna austriacka, córka Fryderyka Eugeniusza i Zofii Doroty, siostra króla Fryderyka I i carycy Marii Fiodorówny. Cf. http://www.chronologia.pl/biogram-elzb17671790t0.html (dostęp: 10 IV 2015). 
nowanie opery, która mogłaby się stać operą narodową. Artysta postanowił wykorzystać modne wówczas i lubiane przez wiedeńczyków motywy orientalne. Aby w pełni poczuć atmosferę, kulturę Wschodu, odwiedzał wiedeńskie targi pełne tureckich sprzedawców handlujących bakaliami, jedwabiem i innymi orientalnymi towarami. Uprowadzenie z seraju, którego premiera odbyła się 16 lipca 1782 r., zyskała ogromną popularność i do końca życia była najczęściej wystawianym dziełem kompozytora.

Oprócz zamówienia opery cesarz starał się także promować młodego kompozytora, organizując turnieje muzyczne. Jeden z takich turniejów odbył się w grudniu 1781 r. między Mozartem a Muzio Clementim ${ }^{8}$. W listownej relacji do ojca ze stycznia 1872 r. Wolfgang nazwał swego przeciwnika „maszyną”, która perfekcyjnie odtwarza zapis nutowy, ale nie ma w tym ni krzty duszy, ni wrażliwości ${ }^{9}$.

Mimo cesarskiej protekcji Mozartowi nie było łatwo wkupić się w łaski wiedeńskiego środowiska muzycznego, dla którego na zawsze pozostał „przybyszem z zewnątrz", intruzem, którego trzeba się pozbyć, uniemożliwić zdobycie jakichkolwiek wpływów. Podejście takie wynikało przede wszystkim z troski o własną pozycję. Biorąc pod uwagę to, że ów „przybysz” otrzymał zlecenie na operę od cesarza już po trzech miesiącach pobytu w Wiedniu, obawy te były w pełni uzasadnione ${ }^{10}$.

Największy konflikt Mozart miał z Antonim Salierim. Ten pochodzący z Werony kompozytor od $1788 \mathrm{r}$. był kapelmistrzem cesarskim, nie musiał więc zabiegać o względy arystokracji, tak jak było to w przypadku Wolfganga ${ }^{11}$. Od początku znajomości ${ }^{12}$ Salieri uważał Mozarta za swego największego wroga. Czuł bowiem, że ten - swoimi zdolnościami i dobrymi relacjami z cesarzem stwarza poważne zagrożenie dla jego pozycji. Robił więc wszystko, co w jego mocy, aby oczernić konkurenta w oczach protektorów. Również Mozart nie odmawiał sobie uszczypliwych komentarzy wypowiadanych publicznie. Pewnego razu do swego przyjaciela Haydna powiedział te oto słowa: „O tobie nie mówię, ale wszyscy inni kompozytorzy to osły"13. Podczas koncertów zaś parodiował utwory konkurenta.

${ }^{8}$ Muzio Clementi (1752-1832) - włoski kompozytor i pianista, współpracownik, później współwłaściciel wydawnictwa muzycznego i fabryki fortepianów w Londynie, która wprowadziła szereg ulepszeń w mechanice fortepianowej. Clementi przyczynił się także do rozwoju faktury fortepianowej. Cf. Encyklopedia muzyki, red. A. Chodkowski, Warszawa 2001, s. 439.

${ }^{9}$ W. D u 1 ę b a, op. cit., s. 151.

${ }^{10}$ N. E 1 i a s, Mozart, portret geniusza, Warszawa 2006, s. 100.

${ }^{11}$ Ibidem, s. 108.

${ }^{12}$ Do pierwszego spotkania obydwu kompozytorów doszło jesienią 1781 r., gdy dwór szukał nauczyciela gry na instrumentach klawiszowych dla księżniczki Elżbiety Wilhelminy von Württemberg. Wówczas posadę tę otrzymał Salieri. Cf. ibidem, s. 110-111.

${ }^{13}$ Ibidem, s. 63. 
Do bezpośredniej - muzycznej - konfrontacji między Wolfgangiem a Salierim doszło w 1786 r., kiedy cesarz zlecił obydwu kompozytorom napisanie krótkich, jednoaktowych oper ${ }^{14}$. W pojedynku tym zwyciężył wówczas Salieri ze swoją operą: Prima la musica, poi le parole (Najpierw muzyka, potem słowa). Dodatkowym ciosem dla Mozarta było wyniesienie Salieriego przez cesarza do rangi następcy Christopha Willibalda Glucka ${ }^{15}$ na stanowisku cesarskiego kapelmistrza dworskiej orkiestry po jego śmierci w 1787 r. Mozart musiał się zadowolić pozycją cesarsko-królewskiego kompozytora.

W sporze Salieri-Mozart karta odwróciła się po tym, jak ten ostatni skomponował operę Cosi fan tutte (Tak czynia wszystkie), która okazała się arcydziełem i przyniosła Wolfgangowi jeszcze większą popularność. Odtąd obydwaj kompozytorzy nie byli już tylko konkurentami, ale prawdziwymi wrogami ${ }^{16}$. Wbrew pozorom konflikt z Salierim sprawiał Mozartowi wiele radości, uwielbiał się drażnić z przeciwnikiem, prowokować kolejne intrygi, których uknucie znacznie nadszarpywały kieszeń konkurenta. Niektórzy z biografów ${ }^{17}$ Wolfganga twierdzą nawet, że był to główny powód, dla którego Mozart nie opuszczał Wiednia.

Wczesna śmierć Amadeusza była więc ogromna ulgą dla Salieriego, który miał ponoć powiedzieć do innego kompozytora: „Dla nas dobrze, że nie żyje. Bo gdyby pożył dłużej, to naprawdę świat nie dałby nam już kromki chleba za nasze kompozycje" ${ }^{\prime 18}$.

Zupełnie inny charakter miała relacja Mozarta z Josephem Haydnem pierwszym z trójki klasyków wiedeńskich. Nie wiadomo dokładnie, kiedy muzycy spotkali się po raz pierwszy. Przetrwały natomiast liczne dowody wzajemnej przyjaźni obydwu kompozytorów. Świadczy o tym chociażby to, że Mozart zwracał się do Haydna vel „papa"19. Przydomek ten przylgnął do niego tak bardzo, że nawet w historiografii o kompozytorze mówi się „papa Haydn”. Jemu także Mozart zadedykował sześć kwartetów smyczkowych. Haydn był z kolei pełen uznania dla talentu Wolfganga, czego dowodem są słowa, jakie powiedział do ojca Amadeusza: „Klnę na Boga i na swój honor, że uważam Pańskiego syna

${ }^{14}$ Tzw. intermezzo.

${ }^{15}$ Christoph Willibald Gluck (1714-1787) - niemiecki kompozytor epoki klasycyzmu, wielki reformator muzyczny. Stawiał znak różności między warsztatem technicznym muzyków a przekazem emocjonalnym, który do tej pory był spychany na drugi plan. $C f$. J. Cho miń s ki, K. Chom i ń s k a, Historia muzyki, t. II, Warszawa 1990, s. 113.

${ }^{16}$ Zdania tego była Konstancja Mozart.

${ }^{17}$ Przykładowo Franc Destouches, uczeń Josepha Haydna, pisze tak w swoich wspomnieniach wydanych w 1815 r. Cf. E. D e s t o u c h e s, Aus der Jugendzeit!, München 1866, s. 56.

${ }^{18}$ Cyt. za: M. B e c k e r, op. cit., s. 113.

${ }^{19}$ D. B o e t t g e r, op. cit., s. $116-117$. 
za największego kompozytora, jakiego znam osobiście lub z imienia; on ma smak, a ponadto wybitną zdolność komponowania"20.

Mozart poznał także trzeciego $\mathrm{z}$ wielkich klasyków wiedeńskich, mianowicie Ludwiga van Beethovena, który w wieku 17 lat, czyli w 1787 r. wizytował $\mathrm{w}$ Wiedniu. Młody Beethoven zjawił się u Wolfganga w domu, chcąc pobierać u niego lekcje. Wówczas - według anegdoty - Mozart zobaczył w nim „,chłopca, który zadziwi niebawem cały świat" ${ }^{21}$. Jednakże plany wspólnych lekcji nie doszły do skutku, ponieważ choroba matki Ludwiga sprawiła, że musiał wracać do Bonn wcześniej, niż planował. Na tym jednak kończą się przyjazne relacje Wolfganga z innymi wiedeńskimi muzykami.

Mimo chłodnego przyjęcia środowiska muzycznego Wiedeń zachwycił Mozarta od początku. Jak napisał w liście do ojca z 4 kwietnia $1781 \mathrm{r} .:$,„[...] jest to najlepsze miejsce na świecie dla mojego zawodu [...], czuję się tu doskonale i korzystam ile się da i tutaj chcę być $[\ldots]^{\prime 22}$. Tutaj wreszcie czuł się wolny, mimo że jego plan dnia był dość napięty: „Około szóstej rano jestem zawsze uczesany. Około siódmej jestem zupełnie ubrany. Potem piszę do dziewiątej. Od dziewiątej do pierwszej daję lekcje. Potem jem, jeśli nie jestem zaproszony do któregoś z domów, gdzie jedzą o drugiej czy nawet trzeciej, jak dziś i jutro do księżnej Zichy i księżnej Thun. Nie mogę nigdy pracować przed piątą czy szóstą wieczorem, a również później często przeszkodzi mi koncert. Jeśli nic mi nie przeszkodzi, piszę do dziewiątej. Potem idę do mojej drogiej Konstancji ${ }^{23}[\ldots]$. O wpół do jedenastej czy jedenastej wracam do domu..."24.

Brak akceptacji ze strony środowiska muzycznego artysta rekompensował sobie na spotkaniach loży wolnomularskiej, do której wstąpił we wtorkowy wieczór, 14 grudnia 1784 r. Przynależność do ruchu masońskiego dawała Mozartowi poczucie wolności, niezależność od bogatych książąt, z którymi teraz był równy i których tytułował braćmi oraz od których otrzymywał intratne zlecenia i propozycje występów. $Z$ dokumentów znajdujących się w wiedeńskich archiwach wyraźnie wynika, że kompozytor był ogromnie zafascynowany ruchem masońskim i z wielką powagą wypełniał obowiązki, jakie wiązały się z przynależnością do tejże organizacji. I choć po śmierci Wolfganga Konstancja próbowała zniszczyć wszelkiego rodzaju świadectwa wskazujące na przynależność jej męża do masonów, to pełna symboliki masońskiej muzyka Mozarta ewidentnie wskazuje, że

${ }^{20}$ Cyt. za: G. W a g n e r, Brat Mozart. Wolnomularstwo $w$ osiemnastowiecznym Wiedniu. Królewska sztuka i jej wpływ na życie i twórczość wielkiego kompozytora. Legenda, mit, rzeczywistość, Gdynia 2001, s. 90-91.

${ }^{21}$ Cyt. za: M. B e c k e r, op. cit., 114.

${ }^{22}$ W.A. M o z a r t, Listy, Warszawa 1991, s. 337.

${ }^{23}$ Przez dwa lata od ślubu Konstancja i Wolfgang mieszkali oddzielnie. $C f$. S. J a r o c i ń s k i, Mozart, Warszawa 1954, s. 85.

${ }^{24}$ Cyt. za: W. D u 1 ę b a, op. cit., s. 168. 
Mozart był wolnomularzem. Myśl o przynależności do loży całkowicie przepełniała zarówno twórczość, jak i życie Wolfganga ${ }^{25}$.

Symbolika masońska pasjonowała kompozytora na długo przed jego przystąpieniem do zgromadzenia. Po przyjęciu do loży starał się tak konstruować utwory, aby w pełni odzwierciedlały nowy system myślowy ${ }^{26}$. Przede wszystkim widać to $\mathrm{w}$ tonacjach, jakie dobierał, komponując dane dzieło. Za tonację typowo masońską uważano Es-dur czy też c-moll, ponieważ trzy bemole ${ }^{27}$, jakie zawierają owe tonacje, odpowiadały symbolicznej trójce, która w masońskim systemie znaków była szczególnie ważna, przywołująca trójcę Ozyrysa, Isis i Horusa będącej gwarancją jedności i równowagi całego wszechświata.

Formą zarobku Mozarta były także liczne występy. Z pomocą przyszła mu również Cecylia Weber, która zaoferowała kompozytorowi nieodpłatnie dach nad głową po tym, jak musiał opuścić swoje lokum w siedzibie Zakonu Szpitala Najświętszej Maryi Panny Domu Niemieckiego w Jerozolimie, w którym pomieszkiwał od chwili przyjazdu do Wiednia ${ }^{28}$. Znajomość Wolfganga $\mathrm{z}$ rodziną Weberów rozpoczęła się w roku 1777, w czasie pobytu Mozarta w Manhaim, gdzie współpracował z tamtejszą orkiestrą, w której mąż Cecylii - Frydolin Weber był basistą. Frydolin zmarł dwa lata później. Wdowa wróciła więc do Wiednia i zamieszkała z dwiema córkami: Konstancją i Zofią. Całą trojkę utrzymywała Alojza - najstarsza córka Cecylii - śpiewaczka w operze cesarskiej.

Mozart przebywał w domu Cecylii do końca sierpnia 1781 r. Przez ten czas plotkom nie było końca, jakoby kompozytor wprowadził się tam wyłącznie ze względu na młode Weberówny będące na wydaniu ${ }^{29}$. Plotki te jednakże nie były bezpodstawne, ponieważ między kompozytorem a sześć lat młodszą Konstancją zawiązała się szczególna wieź. ,[...] Nie potrafię dobrze wythumaczyć ci mojego wrażenia: jest to rodzaj pustki, która sprawia mi ból, jakaś tęsknota, która nigdy nie będąc zaspokojona, nie ustaje, wciąż trwa i rośnie z dnia na dzień $[\ldots]^{\prime 30}$ tak Wolfgang pisał do swej Konstancji w 1791 r., kiedy ta z powodu problemów zdrowotnych wyjechała do uzdrowiska w Baden.

Pani Weber przychylnym okiem patrzyła na wzajemną skłonność młodych ku sobie. Bez skrupułów pchała córkę w ramiona kompozytora, będąc zdania, że jedynym celem w życiu kobiety jest znalezienie męża. Chcąc zapewnić przyszłość Konstancji, podstępem podsunęła Mozartowi świstek papieru, na podsta-

${ }^{25}$ Ibidem, s. 108.

${ }^{26}$ Przykładem takiego dzieła jest opera Czarodziejski flet.

${ }^{27}$ Bemol - znak chromatyczny powodujący obniżenie dźwięku o półtonu. Cf. Encyklopedia muzyki..., s. 158.

${ }^{28}$ D. B o e t t g e r, op. cit., s. 95.

${ }^{29}$ Ibidem.

${ }^{30}$ Cyt. za: W. D u 1 ę b a, op. cit., s. 154. 
wie którego kompozytor zobowiązał się poślubić pannę Weber w ciągu trzech lat, a w razie odstąpienia od umowy płacić jej miesięczną pensję.

W przeciwieństwie do pani Weber Leopold nie popierał romansu swego syna, o czym otwarcie komunikował w listach. Nie pomogły pochwały, których nie szczędził Wolfgang, opisując swoją wybrankę. Przepaść między ojcem i synem pogłebiała się coraz bardziej ${ }^{31}$.

Ślub odbył się 4 sierpnia 1782 r. w katedrze św. Szczepana w Wiedniu, w trzy tygodnie po premierze Uprowadzenia z seraju, opery, którą Wolfgang dedykował swojej małżonce. Owa opera, mimo że odniosła niekwestionowany sukces w Wiedniu, nie zaszczepiła tradycji na śpiewogrę. W 1783 r. cesarz podjął decyzję o rozwiązaniu trupy niemieckiej i ponownym sprowadzeniu włoskich muzyków. Wolfgang miał nadzieję, że to tylko chwilowy kryzys, lecz kierujący włoskim zespołem kapelmistrz Antonio Salieri ani myślał o łatwym oddaniu swego stanowiska.

W życiu operowym Wiednia na nowo nastała hegemonia Włochów. Mozart aż do 1786 r. nie otrzymał zlecenia na operę ${ }^{32}$. Mimo to lata $1784-1785$ należały do wyjątkowych w życiu Amadeusza. W stolicy monarchii habsburskiej panowała wtedy swoista moda na Mozarta. Zapraszano go wszędzie: na rauty, przyjęcia, publiczne akademie. Między 26 lutego a 3 kwietnia 1784 r. dał 22 koncerty. Przeciętny roczny dochód kompozytora wynosił przeszło 2400 guldenów, a niekiedy nawet 3725 guldenów. Dla porównania roczny dochód nauczyciela szkoły podstawowej wynosił około 130, a profesora uniwersytetu około 600 guldenów $^{33}$.

W tym samym czasie Wolfgang skomponował także cztery koncerty na fortepian oraz kwintet fortepianowy. Dzieła te uważał za swoje najlepsze, jakie kiedykolwiek stworzył; jak stwierdził w liście do ojca - „wywołują [one - J.J.] prawdziwy dreszcz"34.

O dobrej passie syna Leopold miał okazję się przekonać na własne oczy, kiedy gościł u Wolfganga i Konstancji od 7 lutego do 25 kwietnia 1785 r. Duma rozpierała jego ojcowskie serce, patrząc na szacunek, z jakim odnoszono się do syna. Również mieszkanie i dochody Wolfganga zaimponowały Leopoldowi, dzięki czemu przekonał się do synowej. Odtąd nie miał do niej żadnych zastrzeżeń ${ }^{35}$.

Tłuste lata nie trwały jednak wiecznie. Już w listopadzie $1785 \mathrm{r}$. zaczęły się problemy finansowe ${ }^{36}$. Hulaszczy tryb życia, nieumiejętność planowania wydatków w niedługim czasie doprowadziły kompozytora do bankructwa. W jego życiu dało się zauważyć pewien paradoks: im więcej zarabiał, tym większe miał

\footnotetext{
${ }^{31}$ Ibidem, s. 152-154.

${ }^{32}$ M. B e c k e r, op. cit., s. 101.

${ }^{33}$ J. C h o m ińs k i, op. cit., s. 120.

${ }^{34}$ D. B o e t t g e r, op. cit., s. 89

${ }^{35}$ Ibidem, s. 90.

${ }^{36}$ S. J a r o c iń s k i, op. cit., s. 116.
} 
problemy finansowe. Trwonił bowiem pieniądze na rzeczy zbędne, zatrudniał służącego, pokojówkę i kucharkę. Przez 10 lat pobytu w Wiedniu przeprowadzał się z rodziną aż 13 razy, gdyż żaden $\mathrm{z}$ apartamentów nigdy w pełni nie zaspokajał jego potrzeb. Ostatnie mieszkanie, do którego wprowadził się w 1791 r., mieszczące się przy Rauhensteingasse 8 , składało się z sześciu pomieszczeń (w tym pokoju bilardowego), łącznie zajmowało $110 \mathrm{~m}^{2}$. Największym jednak problemem okazał się hazard, któremu Mozart oddał się bez reszty. W pewnym momencie bardziej interesowało go pojawienie się w Wiedniu znanego gracza aniżeli słynnego muzyka. Ponieważ w kartach nie miał szczęścia, popadał w liczne długi. Aby je spłacić, zapożyczał się u swoich przyjaciół ${ }^{37}$.

Kiedy wieści o nowym hobby Mozarta zaczęły docierać do wiadomości publicznej, coraz mniej możnych oferowało swoją protekcję. Podstawą formą zarobku Wolfganga były lekcje udzielane arystokratycznej dziatwie.

Wyjątkowo trudny dla Wiednia, a przez to i dla Mozarta, był rok 1788. Cesarz prowadził wówczas wojnę z Turkami, celem nadrzędnym było oszczędzanie, by móc finansować armię. Ostatnią rzeczą, o której myślał wtedy Józef II, było zamawianie oper. Aby zdobyć pieniądze, Mozart musiał wyjechać do północnych Niemiec. „Taki jest niestety mój los, ale tylko w Wiedniu aż tak przeciwny, że nie mogę nic zarobić, nawet kiedy chcę...."38 - pisał do swego przyjaciela 12 lipca 1789 r. $^{39}$ Podczas dwumiesięcznej wyprawy udało mu się zarobić całkiem pokaźną sumkę 1285 guldenów, jednakże pieniądze wystarczyły Wolfgangowi na zaledwie pięć tygodni.

Niespokojna sytuacja na arenie międzynarodowej spowodowana rewolucją francuską także negatywnie wpłynęła na karierę Amadeusza. W 1791 r. Józef II zdecydował zdjąć z afisza cieszącą się ogromnym zainteresowaniem operę $C z a-$ rodziejski flet, w której doszukał się licznych haseł rewolucyjnych i masońskich. $\mathrm{Z}$ uwagi na życie swej siostry Marii Antoniny niechętnie patrzył na rozprzestrzenianie się radykalnych nastrojów na terenie monarchii habsburskiej. $Z$ dużą nieufnością podchodził zatem do działalności lóż masońskich, a nawet zarzucał, że to za sprawą masonerii doszło do detronizacji francuskiej pary królewskiej, a cała rewolucja jest masońskim spiskiem. Mimo wielu trudności, jakie niosła ze sobą demonstracja swoich masońskich ideałów, Mozart nigdy nie zrezygnował z przynależności do „sztuki królewskiej”. Był wolnomularzem sercem i duszą, co przynosiło niewątpliwą chlubę ruchowi masońskiemu. Swą fascynację zaszczepił nawet ojcu oraz Josephowi Haydnowi, którzy pod wpływem Wolfganga również

37 Głównie u Michaela Puchberga. Dowiadujemy się o nim z licznej korespondencji z lat 1787-1789. Były to z reguły prośby Mozarta o kolejną pożyczkę. Cf. W.A. M o z a r t, op. cit., s. $45,213,320$.

${ }^{38}$ Cyt. za: M. B e c k e r, op. cit., s. 122-123.

${ }^{39}$ Ibidem. 
wstąpili do loży. Także wolnomularze okazali swą lojalność wobec „brata Mozarta" i po jego śmierci zaopiekowali się żoną i dziećmi Wolfganga, gdyż tak nakazywał regulamin masoński.

Wolfgang Amadeusz Mozart zmarł 5 grudnia 1791 r., pięć minut przed godziną pierwszą w nocy. Pochowano go już 6 grudnia na cmentarzu St. Marx bez orszaku pogrzebowego, w nieznanym miejscu. Nasuwa to wiele pytań: dlaczego Mozarta pochowano już następnego dnia, dlaczego w nieznanym miejscu i czemu nie towarzyszył mu żaden kondukt pogrzebowy?

Kompozytor nie żyje od 224 lat, mimo to jednak w Wiedniu nadal istnieją miejsca i budynki, które go pamiętają. Jednym $\mathrm{z}$ nich jest kamienica na ul. Domgasse, w której mieszkał. Tu skomponował m.in. Wesele Figara, 10 koncertów fortepianowych, koncert na róg i sześć kwartetów smyczkowych poświęconych Haydnowi. Tu przyjmował Josepha Haydna i Ludwiga van Beethovena. Od $2006 \mathrm{r}$. w budynku tym mieści się muzeum poświęcone Mozartowi.

Innym „pamiętającym” Wolfganga miejscem jest Biblioteka Narodowa (dawniej Dworska), którą odwiedzał każdej niedzieli, oddając się muzycznej edukacji. Ku pamięci kompozytora w 1859 r. na zlecenie władz wiedeńskich ustawiono nagrobek na cmentarzu St. Marx. W 1896 r. w ogrodach Burggarten stanął pomnik, a w 1905 r. fontanna zwana „Fontanną Mozarta” lub „Czarodziejskim Fletem”. Bezapelacyjnie jednak największą pamiątką, jaką pozostawił po sobie Wolfgang Amadeusz Mozart, jest jego muzyka.

\section{JOANNA JASITCZAK}

\section{Music Vienna of Wolfgang Amadeus Mozart (1781-1791)}

Vienna under Maria Theresa (1740-1780) and Joseph II (1780-1790) control was the center of the culture all of German - speaking area. Music, literature and theatre was the complement to the imperial power. That is why Vienna was a perfect place to live for artists, who could lean on emperor support. One of these artist who wanted to settle down in Vienna was Wolfgang Amadeus Mozart (1756-1791). In spite of not being welcome by music community Mozart spent last 10 years of his life in this city earning lots of money for his compositions. Unfortunately, the incompetent management of his own budget, rollicking lifestyles drove him and his wife - Constanze Mozart into bankruptcy. But before it happened, Amadeus became a part of this musician multicultural capital of eighteenth-century Europe, setting - with his friends: Joseph Haydn and Ludwig van Beethoven - new trends in music, which will be later called: Vienna's classicism.

In addition of great concerts that he played, Amadeus had his routine in Vienna that he used to like a lot. As we know from his letters to his father, Mozart's schedule of the day was perfectly planned and put together. He used to wake up early and give a piano lessons, then he had some meetings, in the afternoon there was always time for composing. Evenings were reserved for Constance. But in spite of his busy schedule he found time for Masons meetings, after he discovered 
this organization. His fascination with the Masonic philosophy was reflected in the works of the artist like: the choice of tone and rhythm of fugitive for Masonic.

Besides of his friends like Haydn, Beethoven or Masons, Mozart had to manage with lots of intrigues involved by less talented composers who couldn't cope with success and popularity of „the newcomer from Salzburg”.

Amadeus seemed not to worry about the lack of acceptance by the Viennese musical environment, recognizing Vienna at his destination. 